\title{
A IDENTIDADE INTERROGADA - PROCESSOS DE INTERPELAÇÃO E DE (DES)RACIALIZAÇÃO NA PERFORMANCE PARDA
}

\author{
THE IDENTITY QUESTIONED - PROCESSES OF \\ INTERPELLATION AND (DE-)RACIALIZATION IN THE PARDA \\ PERFORMANCE
}

Júnia Cristina Pereira'

\begin{abstract}
RESUMO: Nesse trabalho, nos inspiramos em Judith Butler (2015a) para mirar o processo de criaçăo artística como uma cena de interpelaçâo na qual a artista produz a si mesma na relaçáo com a alteridade, expressando-se de forma reflexiva a partir de um lugar de fala social, produzindo um relato de si mesma a partir do contato com a alteridade. No caso da performance Parda, aqui relatada, a interpelaçáo racial póe em jogo os significados da mestiçagem, levando em conta o histórico brasileiro da violência colonial e do embranquecimento como política pública, e busca desestabilizar as estruturas racistas que regem as normas de reconhecimento, rejeitando a imobilizaçâo de construçōes identitárias.
\end{abstract}

PALAVRAS-CHAVE: performance, identidade, interpelaçăo, racializaçăo, mestiçagem.

\begin{abstract}
In this article, we get inspired by Judith Butler (2015a) to focus on the process of artistic creation as a scene of interpellation. The artist creates herself in relation to the otherness, expressing herself reflectively from a place of social talking, thus producing a story of the self from the contact with the other. In the case of the Parda performance here described, the racial interpellation plays with meanings of miscegenation, taking into account the Brazilian background of colonial violence and whitening as a public policy and looking forward to destabilize racist structures that inform rules of recognition, thus rejecting steady identity constructions.
\end{abstract}

KEYWORDS: performance, identity, interpellation, racialization, miscegenation.

Este trabalho apresenta e analisa a performance Parda $(2018)^{2}$, uma produçâo artística da autora do artigo, observando-a como uma cena peculiar de interpe-

1 Professora Adjunta na Universidade Federal da Grande Dourados (UFGD). Doutora em Artes Cênicas pela Universidade Federal da Bahia (UFBA).Contato: juniapereira@ufgd.edu.br

2 A performance Parda foi realizada por duas vezes no ano de 2018: em setembro no Teatro 171 (Belo Horizonte/MG), em novembro no Espaço Cultural Casulo (Dourados/MS). O trabalho explora a imagem e 
laçăo ${ }^{3}$, na qual a artista parte da necessidade de relatar a si mesma, narrar o seu lugar de fala à alteridade que a interpela. Nessa cena, elementos pessoais e subjetivos da autora se mesclam a marcadores sociais, localizando sua voz a partir de marcadores de gênero, raça e classe social: a sujeita que produz a obra artística, nesse processo, produz a si mesma como autora. Tal operaçăo de relato/criaçâo de si se dá sempre a partir de uma relaçâo com o outro. De acordo com Judith Butler (2015a):

cada relato que damos acontece numa cena de interpelaçáo. Além disso, a cena de interpelaçăo, que poderíamos chamar de condiçăo retórica da responsabilidade, significa que enquanto estou engajada em uma atividade reflexiva, pensando sobre mim mesma e me reconstruindo, também estou falando contigo e assim elaborando uma relaçăo com um outro na linguagem. $\mathrm{O}$ valor ético da situaçăo, desse modo, náo se restringe à questăo sobre se o relato que dou de mim mesma é ou năo adequado, mas refere-se à questăo de que, se ao fazer um relato de mim mesma, estabeleço ou năo uma relaçấo com aquele a quem se dirige meu relato, e se as duas partes da interlocuçấo se sustentam e se alteram pela cena de interpelaçấo. (BUTLER, 2015a, p. 70)

Na origem da performance Parda, situamos as cenas de interpelaçáo protagonizadas pela autora em dois momentos: num primeiro momento o contato com os Kaiowá e Guarani no Mato Grosso do Sul e num segundo momento o contato com produçōes artísticas e teóricas do teatro negro na cidade de Salvador, estado da Bahia. Frente a sujeitos(as) indígenas e negros(as), a autora é levada a pensar sobre sua constituiçâo mestiça ou parda. De acordo com o censo do IBGE ${ }^{4}$ de 2010, a populaçấo parda constitui 43,1\% da populaçấo brasileira, ou 82 milhóes de pessoas. Parda, no Brasil, é a pessoa mestiça, descendente de brancos, negros e/ou - embora menos reconhecidamente - indígenas. Sabemos que tal miscigenaçāo se iniciou a

a leitura racial do corpo da performer, e compóe-se de uma instalaçâo fotográfica e audiovisual, da presença da artista e das interaçôes com o público. Ficha Técnica: Concepçăo e performance: Júnia Pereira, Imagens: Raique Moura e Bruno Augusto.

3 Nos apropriamos aqui da teoria de Althusser (1980), para a qual a ideologia (representaçăo da relaçăo imaginária dos indivíduos com suas condiçóes de existência), por meio dos aparelhos ideológicos de estado (que nâo sâo necessariamente estatais), interpela os indivíduos como sujeitos, pois os constitui materialmente como sujeitos de práticas ideológicas: "Sugerimos entăo que a ideologia "age" ou "funciona" de tal forma que "recruta" sujeitos entre os indivíduos (recruta-os a todos), ou "transforma" os indivíduos em sujeitos (transforma-os a todos) por esta operaçāo muito precisa a que chamamos a interpelaçāo, que podemos representar-nos com base no tipo da mais banal interpelaçáo policial (ou náo) de todos os dias: "Eh! Você". Se supusermos que a cena teórica imaginada se passa na rua, o indivíduo interpelado volta-se. Por esta simples conversâo física de 180 graus, torna-se sujeito. Por quê? Porque reconheceu que a interpelaçăo se dirigia "efectivamente" a ele, e que "era de facto ele que era interpelado" (e nâo outro). A experiência prova que as telecomunicaçóes práticas da interpelaçáo sâo de tal maneira que, praticamente, a interpelaçăo nunca falha a pessoa visada: chamamento verbal, assobio, o interpelado reconhece sempre que era a ele que interpelavam." (ALTHUSSER, 1980, p.99-100). Butler (2015a) retoma esse termo para tratar da cena na qual um(a) sujeito(a) produz um relato de si, o qual necessariamente transforma a si e ao outro para quem se dirige o relato.

4 Instituto Brasileiro de Geografia e Estatística (IBGE) vem realizando recenseamentos de dez em dez anos. No último Censo Demográfico, cuja coleta de dados foi feita em 2010, a investigaçáo da cor ou raça foi realizada para a totalidade da populaçâo brasileira, a partir da autodeclaraçấo em uma das seguintes categorias: branca, preta, amarela (ou oriental), parda e indígena. O resultado contabilizou um total de 191 milhóes de habitantes, sendo 91 milhôes de brancos (47,7\%), 15 milhôes de pretos (7,6\%), 82 milhôes de pardos (43,1\%), 2 milhóes de amarelos (1,1\%) e 817 mil indígenas (0,4\%). (IBGE, 2011) 
partir de violência sexual engendrada, sobretudo, por homens brancos contra mulheres negras e indígenas, no contexto de toda a violência do processo colonial.

Além disso, o significado de parda(o) se relaciona também à política pública de branqueamento da populaçăo brasileira, implementada nas primeiras décadas do período republicano, sob o respaldo de teorias racistas e eugênicas. Grosso modo, de acordo com teorias evolucionistas vigentes à época, a mistura de raças ${ }^{5}$ heterogêneas constituía-se um erro nacional, que levaria à degeneraçâo do indivíduo e da coletividade (STEPAN, 2004). Assim, estando o território brasileiro já povoado por diferentes grupos humanos, estaria o projeto de naçâo brasileira fadado ao fracasso, pois o povo miscigenado náo teria qualidades suficientes para construir um país civilizado. Nesse mesmo contexto de pensamento, teorias eugênicas consideravam que existiria uma superioridade da "raça ariana" ou de origem europeia, sendo que negros e indígenas pertenceriam a raças inferiores. A partir dessas teorias racistas, a miscigenaçâo deixou de ser vista como somente um grande mal e passou a ser vista, também, como possibilidade de cura para a populaçâo brasileira. Para ser vista como curativa, a miscigenaçăo deveria se dar, predominantemente, com a "raça branca". Acreditava-se que as características das pessoas brancas, por serem superiores, iriam sempre prevalecer, de forma que paulatinamente a populaçăo seria embranquecida ou desracializada, ajudada por políticas de saneamento e higiene (STEPAN, 2004). Nesse contexto, podemos afirmar que embranquecer-se e tornar-se parda, seria ajudar a construir um projeto de naçâo mais branca ou quase branca, e por isso melhor.

Tais crenças motivaram o incentivo à vinda de imigrantes europeus nas primeiras décadas do período republicano, sendo que a esses imigrantes foram ofertados trabalho assalariado e privilégios na aquisiçăo de terras, vantagens que nâo possuía aqui a populaçāo negra recém liberta. Já a populaçâo indígena, em muitos casos, foi expulsa de seus territórios, os quais foram doados pelo Estado aos novos imigrantes. No contexto regional, essa história se repetiu na regiăo hoje denominada Mato Grosso do Sul, décadas mais tarde, como política de "ocupaçăo"6 do

5 Contemporaneamente, considera-se o conceito de "raças humanas" como apenas cultural, sem base biológica ou científica. Até o final do século XX, entretanto, acreditava-se que as diferenças fenotípicas entre seres humanos de diferentes origens constituíam diferentes raças, o que no contexto do colonialismo serviu como justificativa moral para diferentes tipos de exploraçăo e de violência. Mesmo, porém, com o fim oficial do racismo científico, a atualidade do racismo se impóe. Segundo Kabengele Munanga (2019): "o racismo no século XXI náo depende mais do conceito biológico de raça, mas sim de outras essencializaçōes políticas, culturais e históricas. (...) As palavras negro, branco, mestiço e indígena nâo sâo sinônimos de raça. Ainda assim, elas representam indivíduos e populaçóes com traços somáticos diferentes. Năo vamos negar que essas diferenças somáticas existem e que, mesmo sem usarmos a palavra raça, jamais deixaráo de servir de motivos de discriminaçáo na cabeça dos indivíduos que receberam uma educaçăo racista." (MUNANGA, 2019, p.110).

6 O território hoje denominado Mato Grosso do Sul esteve ocupado por centenas de anos por povos originários que, a partir do século XIX, foram paulatinamente destituídos de suas terras por meio de açóes do Estado Brasileiro como a criaçâo da Lei de Terras (1850) e do SPI - Serviço de Proteçâo ao Índio (1910), que depois se tornou FUNAI. A Reserva Indígena de Dourados, criada em 1917, faz parte de um projeto de confinamento dos povos indígenas da regiăo, que visava liberar as terras indígenas para a empresa colonial e estabelecer de forma coercitiva para a populaçăo indígena um modo de vida militar e cristăo. Grande parte da populaçăo kaiowá resistiu a esse confinamento, embrenhando-se nas matas, enquanto mata houve. Porém, em 1943, chegam agricultores assentados para ocupar as Colônias Agrícolas Nacio- 
território. Isso resultou na apropriaçăo indevida de muitos tekoha ${ }^{7}$ ou territórios há muito ocupados pelas populaçōes Kaiowá e Guarani. Entretanto, a narrativa dominante no imaginário brasileiro acerca do processo de mestiçagem náo carrega a memória da extrema violência colonial ou do projeto de embranquecimento e desracializaçâo como política pública. De acordo com essa narrativa, sintetizada por Gilberto Freyre em "Casa Grande e Senzala", a mestiçagem é o resultado de uma convivência cordial, íntima e bem-sucedida entre brancos, negros e indígenas:

\begin{abstract}
Híbrida desde o início, a sociedade brasileira é de todas da América a que se constituiu mais harmoniosamente quanto às relaçóes de raça: dentro de um ambiente de quase reciprocidade cultural que resultou no máximo de aproveitamento dos valores e experiências dos povos atrasados pelo adiantado; no máximo de contemporizaçấo da cultura adventícia com a nativa, da do conquistador com a do conquistado. (FREYRE, 2003, p. 160)
\end{abstract}

Ao olhar contemporâneo, a narrativa de Freyre se torna contraditória, pois a classificaçăo entre povos "adiantados" e "atrasados" năo pode mais ser aceita com naturalidade, e revela ao olhar de hoje o racismo existente em sua argumentaçăo, racismo esse, avesso à noçâo de "reciprocidade" que evoca. Em sua época, porém, e no contexto do pensamento eugênico, Freyre chegou a ser visto como um teórico progressista, pois avesso ao determinismo racial e climático, segundo o qual as "raças inferiores" e o "ambiente tropical" levariam necessariamente à degeneraçấo social brasileira. Freyre busca afastar as explicaçóes genética e climática, argumentando que a má alimentaçăo e a falta de higiene é que săo causadoras dos problemas sociais brasileiros. Soma-se a isso a descriçấo amena e positiva que faz do processo de mestiçagem e temos os fundamentos para uma reediçăo do projeto de "salvamento" da populaçăo, nâo mais protagonizado, como no período colonial, pela conversấo ao cristianismo, mas sim via saneamento, educaçăo e mestiçagem. Hoje, porém, a populaçăo negra e indígena vem cada vez mais denunciando o cinismo dessa falsa cordialidade da "democracia racial".

Paradoxalmente, vemos emergir na atualidade discursos abertamente racistas e eugênicos, como as declaraçôes do atual vice-presidente da República, que durante sua campanha presidencial em 2018 afirmou em uma reuniâo pública que o brasileiro herdou a "indolência" do índio e a "malandragem" do africano. O mesmo candidato, que se autodeclarou indígena ao registrar sua candidatura à Justiça Eleitoral, às vésperas da eleiçăo exibiu o neto de pele branca para jornalistas e co-

nais criadas pelo Estado Novo de Getúlio Vargas, e iniciam-se os confrontos diretos entre indígenas e karaís (nâo indígenas) pela ocupaçăo do território. A partir dos anos 1960, intensificou-se a colonizaçăo sistemática e efetiva dos territórios kaiowá e guarani, no contexto do regime militar e ditatorial. Começou a se delinear um projeto de agricultura mecanizada para a regiăo, dando origem ao que chamamos hoje de agronegócio, que expulsou os grupos indígenas de forma violenta de seus territórios. A partir da década de 1980, tais grupos passam a se organizar por meio de uma assembleia, a AtyGuasu, para se fortalecerem na luta pela retomada de suas terras tradicionais. Amparados pela Constituiçáo de 1988, e graças a uma luta persistente, conseguiram recuperar 16 tekohas até 2003 (CHAMORRO, 2015). Nos últimos anos, porém, os ruralistas também se organizaram, dominando a cena política nacional e promovendo grandes retrocessos na conquista dos direitos indígenas na regiăo, direitos esses simbolizados pelo direito à terra como direito central que tem sido violado.

Palavra guarani para território. Em traduçăo livre: "lugar onde se é". 
mentou: "Meu neto é um cara bonito, viu ali? Branqueamento da raça" (apud PIRES, 2018, on-line).

Nesse contexto em que o racismo brasileiro escancara toda a sua atualidade, a autora investiga sua constituiçâo mestiça como lugar de fala e de expressáo artística. Um corpo pardo pode simbolizar um corpo salvo pelo Estado, por meio de políticas de higiene, saneamento, educaçăo e branqueamento; políticas essas também dirigidas há séculos aos povos originários sob a forma geral da "civilizaçăo de selvagens". Nas palavras de Gilberto Freyre: "sendo a mestiça clara e vestindo-se bem, comportando-se como gente fina, torna-se branca para todos os efeitos". (FREYRE, 1951, p. 630) Em sua experiência pessoal, a autora buscou identificar o processo de embranquecimento e desracializaçâo de si mesma, e o encontrou, sobretudo, no apagamento histórico da ancestralidade e no processo de socializaçăo/escolarizaçấo que vivenciou. Para melhor entrelaçar os aspectos pessoais de sua trajetória à reflexăo que empreende, a autora irá, a partir de agora, se expressar em primeira pessoa.

Mestiça, quando criança me identificava como "morena clara" e mais tarde, em pesquisas e formulários oficiais, sempre me autodeclarei como parda. Quando se fala em branqueamento, a expectativa é que à medida que se procura os antepassados, as marcas de negritude ou indianidade fiquem mais evidentes. Entretanto, nâo é assim em minha família. Ao buscar reconstruir minha árvore genealógica, encontrei muitas lacunas e as poucas informaçôes que obtive se revelaram insuficientes para o conhecimento de minha origem racial. À exceçâo de uma bisavó de origem italiana, nâo há narrativas de origem da família que possam dar suporte para a interpretaçâo das poucas fotografias encontradas. Sabemos que sessenta anos apenas separam o fim oficial da escravidâo e o nascimento de minha máe. Sabemos também que o processo de colonizaçăo em Minas Gerais escravizou, dispersou e exterminou etnias indígenas inteiras. Assim, possivelmente, as lacunas na história da minha família estejam relacionadas à presença negra e/ou indígena, e ao apagamento de histórias traumáticas de violência e sofrimento. Nesse sentido, parece significativo que a única história de origem remeta ao continente europeu. Porém, na ausência de informaçôes, a hipótese de uma ancestralidade negra ou indígena torna-se mera especulaçáo, que encontra apoio somente no fenótipo de minha mâe, que reconheço como negra, e que, no entanto, nâo se autodeclara como negra, mas sim, como "morena".

Apesar de crescer em uma família desracializada, nâo é sem juízo de valor que traços fenotípicos ligados à mestiçagem eram significados no discurso familiar: lembro de minha măe elogiando de forma especial o meu nariz, mais fino que o seu, e meu cabelo, também mais liso em relaçâo ao seu. Ela se sentia feliz em perceber que seus traços fenotípicos mais ligados à negritude - e associados, em sua vivência, a experiências negativas de racismo e discriminaçâo social - foram transmitidos a mim de forma suavizada. Pode-se imaginar como tais "elogios" tinham um impacto ambíguo em minha subjetividade: por um lado, minha mâe se orgulhava de mim; por outro lado, tal orgulho tinha origem em sua própria vergonha, e no meu posicionamento como "outro" em relaçấo a ela: eu nâo era como ela. Ao recordar tais experiências, me perguntei no início do processo criativo da performance: 
como construir uma imagem positiva de si à custa da separaçâo familiar e da negaçâo de sua origem?

Em meio ao desconforto dessa percepçâo difusa e lacunar, sobre um aspecto de minha família năo tenho dúvida: viemos da pobreza. Foi a partir da experiência da pobreza, em minha infância e adolescência em Congonhas/MG, que experimentei a discriminaçăo social, e embora hoje perceba que o que eu nomeava como pobreza estava entremeado de aspectos raciais, naquele momento isso nâo era distinguido por mim. As relaçóes entre racismo e desigualdade socioeconômica no Brasil săo profundas, e muitas vezes, na experiência vivida, tais noçōes se mascaram mutuamente. A partir do apagamento histórico da história familiar, cria-se para as pessoas pardas uma noçấo indeterminada de identidade racial, e o racismo torna-se pouco visível. Dessa maneira, pessoas pardas e pobres tendem a imaginar que as causas de sua exclusáo social se resumem ao aspecto econômico. Por meio dessa percepçâo ilusória, cria-se um ideal de inclusâo social, muitas vezes ligado à noçăo de esforço e ao processo de escolarizaçăo. Em minha biografia, o esforço é um elemento presente. Comecei a trabalhar aos doze anos de idade vendendo cosméticos, e aos quatorze anos passei a trabalhar também como atriz. Paralelamente aos estudos e à minha carreira artística, sempre tive que conciliar outros trabalhos, a maioria deles precarizados, para garantir minha subsistência. Mas náo quero falar aqui do esforço de se trabalhar muito e de trabalhar duro, mas sim de um tipo específico de esforço: o esforço de adaptaçăo.

Durante minha juventude em Belo Horizonte/MG, cursei a graduaçâo em Artes Cênicas na UFMG. Nesse período, eu tinha a sensaçăo de transitar por universos totalmente distintos onde o meu valor e o valor das coisas se alteravam totalmente, dependendo do ambiente em que estava. Por exemplo: uma vez estava trabalhando como artista criadora em um espetáculo e assim que terminava a sessăo eu tinha que sair bem depressa para ir trabalhar como garçonete em uma casa de shows. Nâo se tratava simplesmente do esforço de exercer duas funçōes no mesmo dia, mas do esforço de transitar no mesmo dia por diferentes imagens de mim mesma. Como artista, eu me sentia valorizada pelo público: eu tinha um nome, uma expressāo poética, meus sentimentos e opiniôes eram valorizados, as pessoas saíam de casa para compartilhar conteúdos comigo. Já como garçonete, eu era apenas braços e máos que anotavam, carregavam, entregavam; ouvidos que escutavam, pernas que moviam objetos. Frequentemente acontecia de colegas artistas ou espectadores que me viam no teatro frequentarem como clientes os locais onde eu trabalhava como garçonete, e eles nâo me reconheciam porque literalmente eles nâo me viam, eu me tornava invisível. Por outro lado, o teatro me exigia uma dedicaçâo extrema, e trabalhando em produçóes independentes do teatro de grupo era impossível prever se haveria cachê e quanto seria, pois tudo dependia do rendimento da bilheteria, muitas vezes insignificante. Já como garçonete, e mesmo em uma relaçăo de trabalho precarizada, eu me sentia segura por ter um horário para entrar e outro para sair, e um valor fixo a receber por meu trabalho. Integrar essas diferentes experiências em minha subjetividade exigia-me um grande esforço. Certamente, nesse processo, aprendi um pouco sobre alteridade, pois estando nesse lugar de trânsito social, eu mesma era a minha própria alteridade. 
A inclusăo/ascensăo social nâo está franqueada a todos(as) que se esforçam, mas apenas a quem consegue ter passabilidade ${ }^{8}$. Dessa maneira, "passar por branca" é o máximo que uma pessoa mestiça pode conseguir ao ascender socialmente, pagando, por isso, um alto preço subjetivo. Devido ao fenômeno conhecido como colorismo ou pigmentocracia, o racismo à brasileira se baseia mais na cor da pele que na origem racial, e assim se estabelecem diferenciaçôes entre pessoas negras, indígenas e mestiças: quanto mais clara a cor da pele, mais as pessoas serăo aceitas socialmente. Mas relutemos um pouco em significar essa "aceitaçăo" como naturalmente positiva: o que significa ser "aceita" ou "incluída"? Uma metáfora bastante usada para explicar o funcionamento dos privilégios na sociedade é a de uma corrida na qual o lugar de chegada é o mesmo para todos(as), porém diferentes sujeitos(as) dăo a largada de lugares diferentes ${ }^{9}$. Se essa metáfora é bastante didática para evidenciar e questionar as desigualdades sociais (e suas interseçôes raciais e de gênero) referentes ao "lugar de partida" de cada um(a) nessa corrida, ao se falar em termos de privilégio, pouco se olha ou se questiona para o "lugar de chegada" dessa corrida, ou seja, para o ideal único de inclusăo/ascensăo social. Muitas vezes, esse ideal é assimilado de forma acrítica como se o valor econômico fosse essencialmente e sempre positivo, e mais ainda, como se fosse um aspecto neutro e năo carregasse consigo aspectos de branqueamento cultural, entre outras normatizaçóes sociais. Em outras palavras: um ideal único de boa vida termina por embranquecer nossos corpos pardos, que desaparecem racialmente no processo de inclusâo/ascensâo social.

Nas palavras do grupo Racionais Mc's: “Acredito que o sonho de todo pobre é ser rico" (RACIONAIS MC'S, 2002, s.p.). Mais do que um sonho, ser rico - e branco, e homem, e heterossexual, entre tantas outras normatizaçôes de nossos corpos - se impóe muitas vezes como a única forma possível de se viver. De acordo com Fanon: "Por mais dolorosa que possa ser esta constataçăo, somos obrigados a fazê-la: para o negro, há apenas um destino. E ele é branco." (FANON, 2008, p.28)

No âmbito da subjetividade, um dos aspectos mais difíceis dessa pesquisa tem sido a percepçăo de minha trajetória artística e acadêmica como um processo de branqueamento cultural. Tal percepçáo desconstrói a narrativa de minha experiência de vida como a de uma pessoa que lutou e luta para realizar seus sonhos, e me apresenta, na fala freyriana, uma imagem de mestiça dócil passável como branca.

8 Apropriamo-nos, aqui, do conceito de passabilidade, tal como utilizado na descriçâo de experiências de pessoas transgênero que desejam ser lidas socialmente como pessoas cisgênero. Tal desejo, porém, acaba muitas vezes se revelando irrealizável ou criando metas injustas para esses(as) sujeitas(os), as(os) quais serăo na maior parte das vezes marcadas(os) com o adjetivo "trans", por mais que se adequem aos padrōes sociais normativos de masculinidade ou feminilidade. De acordo com Júlia Clara Pontes e Cristiane Gonçalves Silva (2017/2018): "Ao estabelecer como objetivo último da transiçấo a possibilidade de 'passar por cis', a experiência da passabilidade como horizonte normativo acaba por definir e aplicar valores aos corpos e, por conseguinte, aos próprios sujeitos, explicitando relaçōes de hierarquia". (Pontes; SILVA, 2017/2018, p.403-404). Nesse sentido, o desejo por passabilidade, embora legítimo, revela uma trama normativa e hierárquica de significados sociais e culturais atribuídos aos diferentes corpos.

9 Essa metáfora foi utilizada em um vídeo conhecido como Corrida por cem dólares (COMECE A PENSAR, [2019]) e, em uma versăo brasileira, Jogo do privilégio branco (ID_BR, [2019]). 
De acordo com Neusa Santos Souza, o modelo de existência branco tem pautado o projeto de vida de pessoas negras que buscam a ascensâo social:

Tendo que livrar-se da concepçâo tradicionalista que o definia econômica, política e socialmente como inferior e submisso, e năo possuindo uma outra concepçăo positiva de si mesmo, o negro viu-se obrigado a tomar o branco como modelo de identidade, ao estruturar e levar a cabo a estratégia de ascensăo social. (SOUZA, 1983, p. 19)

Tal ascensăo, assim estruturada como um projeto individual, afasta a pessoa negra de seu grupo, e lhe cobra o preço caro da negaçăo de si mesma: “É a história de uma identidade renunciada, em atençâo às circunstâncias que estipulam o preço do reconhecimento ao negro com base na intensidade de sua negaçăo" (SOUZA, 1983, p. 23).

Souza nos fala da assimilaçăo da identidade branca por pessoas negras que ascendem socialmente, mas também da constituiçăo de um mito negro, qual seja, a ideia de que pessoas negras estăo associadas a características de significaçăo predominantemente negativa: "O irracional, o feio, o ruim, o sujo, o sensitivo, o superpotente e o exótico săo as principais figuras representativas do mito negro" (SOUZA, 1983, p. 27).

A partir de seu raciocínio, nos arriscamos a pensar o que seria o mito do embranquecimento, ou o discurso acerca da pessoa parda. Para a comunidade branca, a imagem da pessoa embranquecida é a de uma pessoa submissa, dócil, inofensiva, esforçada, domesticada, trabalhadora, religiosa, "direita". Podemos pensar como origem desse mito a figura das "mucamas", escolhidas para fazerem os serviços de dentro de casa grande, e sendo, portanto, mais bem tratadas, vestidas e alimentadas; ou, ainda, as pessoas indígenas convertidas, que deixaram de viver na mata (Ka'agua ${ }^{10}$ para viverem reduzidas em missóes jesuíticas, e "protegidas" pela instituiçâo Companhia de Jesus.

A pessoa embranquecida é aquela que se esforçará muito para ser "salva" pelas políticas de branqueamento. Lembro-me bem da minha infância, em como minha mâe sempre nos educou para que, no ambiente escolar, nâo questionássemos a autoridade, náo nos revoltássemos contra as injustiças, náo nos envolvêssemos em brigas, mas antes ficássemos sempre calados(as), nos esforçássemos muito, nos destacássemos pelo mérito, fôssemos os(as) melhores, aproveitássemos as oportunidades. Já para a comunidade negra ou indígena, o mito do embranquecimento pode se caracterizar, de forma negativa, pela alcunha de traidor(a) e de "vendido(a)", ilustrada pela figura de Malinche ${ }^{11}$.

10 O termo guarani Ka'agua, significa, em traduçâo livre: "que vivem na (-gua) mata (ka'a)". Originalmente usado de forma pejorativa como sinônimo de "selvagem" ou "nâo civilizado", a expressâo deu origem ao termo Kaiowá, que foi ressignificado e adotado como autodenominaçăo por indígenas da regiâo sul do hoje denominado Mato Grosso do Sul.

11 Malinche (1496 - 1529 ou 1551), personagem indígena histórica na conquista das Américas, foi dada de presente aos espanhóis e se tornou tradutora e amante de Hernán Cortés, auxiliando na conquista do México. Sua figura ainda é lembrada no imaginário mexicano como a de uma traidora. Malinche foi também măe de mestiços, o que a associa à fundaçăo da naçăo mexicana. 
Tais significaçōes do "mito pardo" me interpelaram, e exigiram-me um relato de mim mesma. Sou essa traidora? Sou essa pessoa salva pela eugenia? Sou esse Frankestein criado em laboratório por cientistas eugênicos? Sou a empregada esforçada? Sou a ignorante de si mesma? Tais perguntas exigiram uma resposta artística, que foi se materializando na performance Parda, desenvolvida em três frentes principais: produçâo de imagens, produçâao textual e açăo performática. A seguir, descrevo cada uma dessas frentes e reverbero as sensaçóes e percepçóes produzidas no contato com o público.

a) Produçăo de imagens

Em 2018, após um período de três meses e meio residindo em Salvador por ocasiăo de meu estágio doutoral, pude ter um contato mais próximo e intenso com a cultura negra e em especial com o teatro negro ali produzido. Se, por um lado, esse contato me fez pensar mais sobre minha condiçáo de parda ou mestiça, por meio de um processo de identificaçáo; por outro lado a socializaçăo em Salvador me trouxe de forma inesperada a percepção de meu "embranquecimento", pois, em nenhuma outra cidade em que estive, fui lida predominantemente como branca, o que me causou, por vezes, desconforto. Sabemos que Salvador é a cidade com maior populaçăo negra fora de África.

Assim, antes de deixar a cidade de Salvador, desejei experimentar em meu corpo uma intervençăo que ressaltasse e afirmasse de forma mais contundente para o olhar do outro a minha condiçáo de mestiça ou de náo-branca, e o meu desejo de assim ser reconhecida. $O$ corpo é político e a construçāo da autoimagem no cotidiano performa nossos devires, desejos e identidades. No campo dos estudos de gênero, o conceito de performatividade permite compreender que uma identidade de gênero năo está fixada pela biologia, mas que pode ser (des)construída por meio da repetiçâo de atos, signos e gestos no meio social (BUTLER, 2015b). Inspirada por esse conceito, desejei implantar tranças em meu cabelo, e, ao agendar a realizaçăo do penteado, me imaginei como uma mulher trans que vai comprar o seu primeiro sutiă.

O resultado da intervençáo me emocionou e foi muito importante para mim, pois além de me sentir mais bonita e poderosa, simbolicamente pude reintegrar em minha subjetividade minha condiçăo de năo branca que sempre me constituiu e que em Salvador passou por um processo de estranhamento ou questionamento. As tranças foram feitas em Salvador no dia 16 de julho de 2018 e marcaram o início da performance Parda. 
Figura 01 - Selfie tirada logo após a implantaçăo das tranças. Salvador, 16 de julho de 2018.

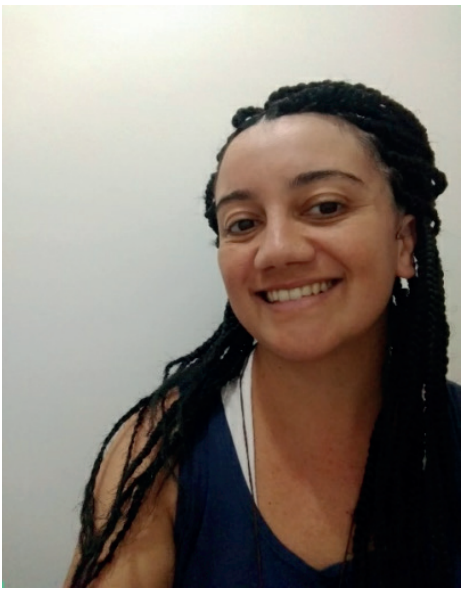

Ao mesmo tempo em que me senti muito bem com as tranças, foi possível perceber que nâo era viável simplesmente transpor o conceito de performatividade da identidade de gênero para a identidade racial, seja porque sấo, na verdade, situaçôes muito diferentes; seja por causa do conceito de apropriaçáo cultural ${ }^{12}$, que problematiza socialmente o meu gesto individual de trançar o cabelo. Assim, na continuidade da investigaçấo acerca da imagem racial do meu corpo, ao invés de seguir no caminho da reivindicaçáo da minha negritude, voltei meu olhar para os problemas e para as lacunas que contradizem essa identidade no meio social, pois foi o que a primeira experiência com as tranças me trouxe como questăo.

Como próxima açâo, ainda em julho de 2018, realizei uma sessáo de fotos e vídeos, nas quais explorei a interaçâo de meu corpo nu com projeçôes de fotos da minha mâe, a fim de relacionar minha imagem à dela e de evidenciar os vestígios que nós duas trazemos de nossa identidade de parda ou "morena", bem como o "branqueamento" fenotípico geracional. Optei por fazer as fotos nua, para que o tom de minha pele se tornasse visível. Além disso, a escolha de um figurino sempre traria informaçôes culturais, de classe ou de origem que interfeririam na leitura racial do meu corpo. A relaçâo estabelecida com as fotos de minha mâe pode ser lida como uma espécie de tentativa de comprovaçấo de minha negritude, mas representa também o próprio fracasso dessa mesma tentativa, uma dança com a minha ancestralidade perdida, e a indagaçăo de uma identidade lacunar. Como toda performance, o sentido está aberto a diferentes leituras, e tenho consciência de que o uso de fotos da minha máe pode ser associado, inclusive, a narrativas genealógicas que tentam justificar fraudes nas cotas raciais. Busquei lidar artisticamente com

12 Expressâo muito debatida na atualidade, designa a utilizaçăo de símbolos de uma cultura por membros de outra cultura. No contexto dos debates, muitas vezes acalorados, pauta-se o esvaziamento do significado cultural do objeto ou símbolo utilizado, em especial no campo da moda. Além disso, também está em discussâo o privilégio de raça, classe ou religiosidade que o grupo ou indivíduo tem para utilizar símbolos que, em seu contexto original, săo alvo de discriminaçâo. 
essa polissemia, que me coloca, virtualmente, também como impostora, aproveitando-me artisticamente de sua potência de desestabilizaçâo.

Figura 02 - A autora em interaçăo com imagens de sua mâe. Fotoperformance. Julho de 2018.

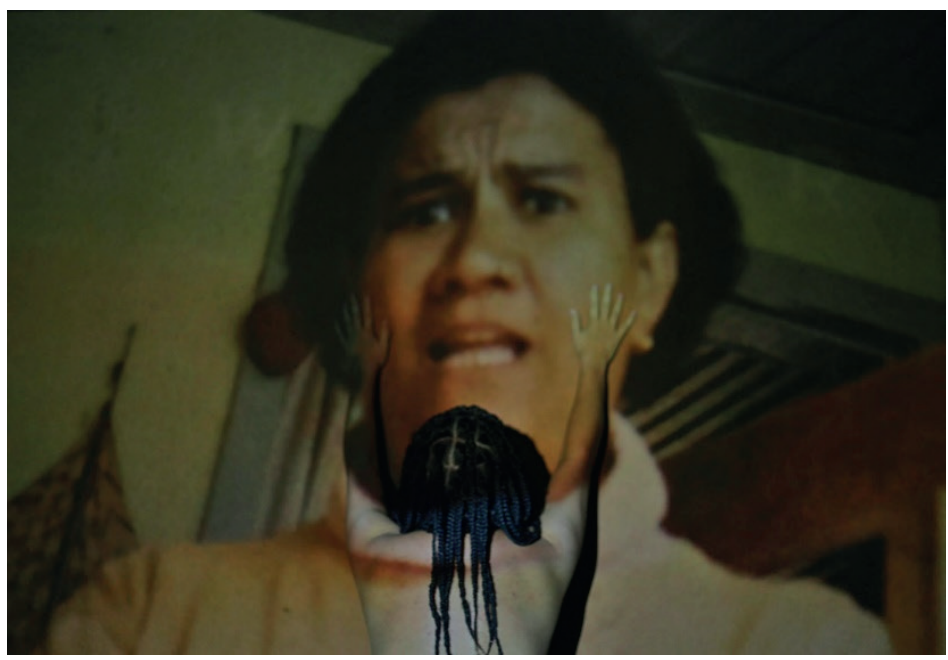

Fotógrafo: Raique Moura.

Figura 03 - A autora em interaçăo com imagens de sua mâe. Fotoperformance. Julho de 2018.

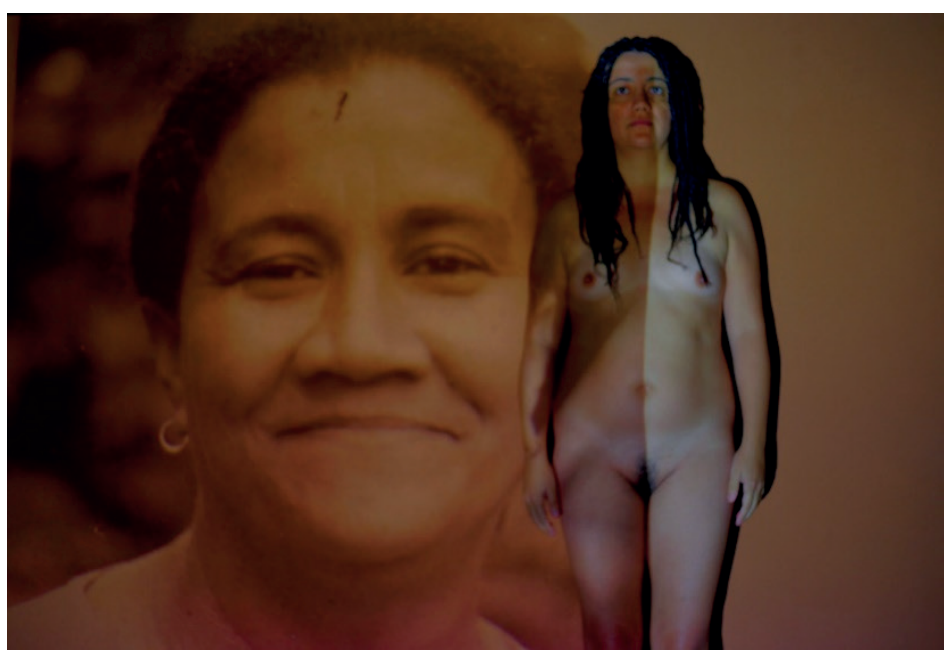

Fotógrafo: Raique Moura.

Outra proposta que trabalhamos nesse ensaio foi a produçâo de imagens a partir da relaçâo entre o meu corpo e o papel kraft, conhecido como papel pardo. A utilizaçấo do termo parda(o) como categoria racial é polêmica, e frequentemente tem sido criticada a partir da expressăo "pardo é papel", e acusada de servir à necessidade de suavizaçấo ou mascaramento da identidade negra. Nessa linha de pensamento, pardos(as) também seriam negros(as), e negros(as) seriam a maioria 
da populaçâo brasileira. De acordo com o professor Kabengele Munanga, os movimentos negros brasileiros nascidos na década de 1970 "tentam dar uma redefiniçăo do negro e do conteúdo da negritude no sentido de incluir neles năo apenas as pessoas fenotipicamente negras, mas também e sobretudo os mestiços descendentes de negros, mesmo aqueles que a ideologia do branqueamento já teria roubado" (MUNANGA, 2019, p.138).

Por outro lado, e também, em especial, no contexto em que se discute tentativas de fraude nas cotas raciais, pardo(a) é uma categoria suspeita, pois designa alguém que pode, por oportunismo, se fazer passar por uma pessoa negra ou por uma pessoa branca. Temos aqui, mais uma vez, a associaçăo com a imagem de Malinche: torna-se suspeita uma pessoa que transita entre dois lados de uma guerra social.

Em meu trabalho, me aproprio do termo parda e, também, da imagem do papel pardo, pois o termo faz parte da minha vivência e da minha construçăo subjetiva, e expressa o "năo-lugar" de saber-se indeterminada racialmente em uma sociedade racista. Ao mesmo tempo, o apropriar-se do papel pardo năo significa construir a partir dele uma imagem estável ou conciliadora de si, na linha freyriana de um processo supostamente harmonioso, alegre e sensual de mestiçagem (FREYRE, 2003), mas pode sim revelar o aspecto traumático da mestiçagem, e provocar reflexóes e questionamentos. A seguir, algumas fotos produzidas com o papel pardo:

Figura 04 - A autora em interaçăo com papel pardo. Fotoperformance. Julho de 2018.

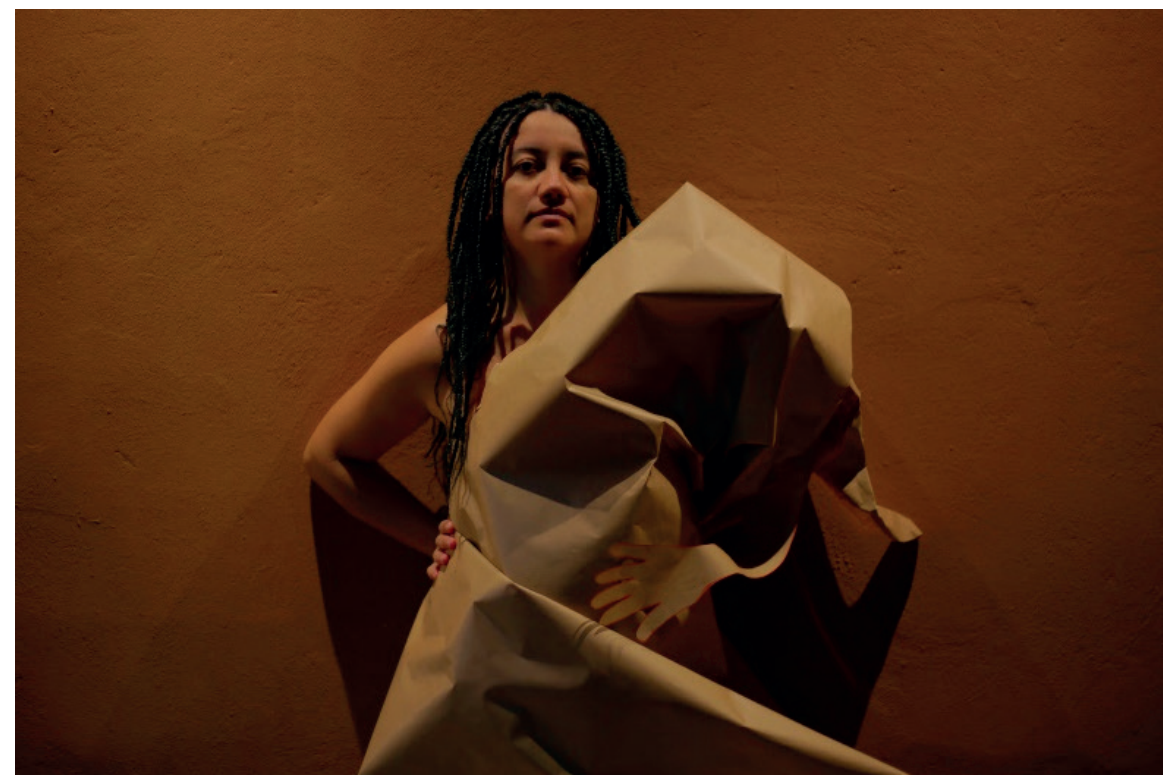

Fotógrafo: Raique Moura. 
Figura 05 - A autora em interaçăo com papel pardo. Fotoperformance. Julho de 2018.

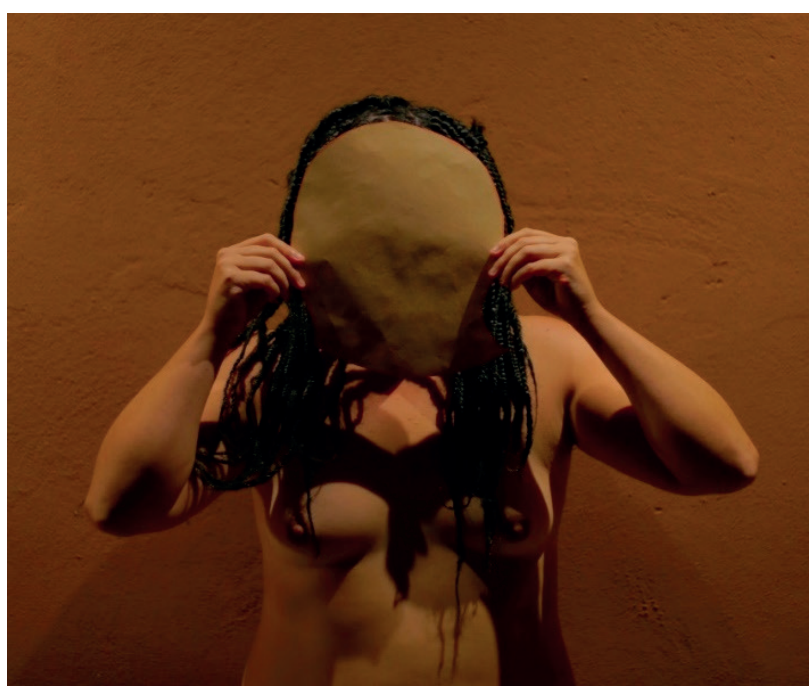

Fotógrafo: Raique Moura.

Além das fotos, também produzimos imagens em vídeo. Um deles, com duraçăo de um minuto e meio, reúne fragmentos do registro que fiz do processo de implante das tranças em Salvador. Em outro vídeo, interajo com um corpo bidimensional de papel pardo, recortado a partir de meu próprio contorno corporal, no qual escrevi algumas palavras relacionadas à temática da mestiçagem. Outra vertente da produçấo de imagens foram intervençôes realizadas nas obras Operários (1933), de Tarsila do Amaral e A Redençâo de Cam (1895) de Modesto Brocos. Em ambos os casos, a intervençăo consistiu em sobrepor recortes de fotografias minhas à imagem de alguns dos personagens representados. No caso de A Redençâo de Cam, uma foto de meu rosto na infância foi sobreposta à criança que simboliza o embranquecimento por meio da miscigenaçăo. Já em Operários, várias imagens de meu rosto foram sobrepostas em vários dos rostos de operários(as), como pode ser visto abaixo na sequência: 
Figura 06 - Montagem de Bruno Augusto, a partir da obra A Redençâo de Cam, de Modesto Brocos (1895). Fotoperformance.

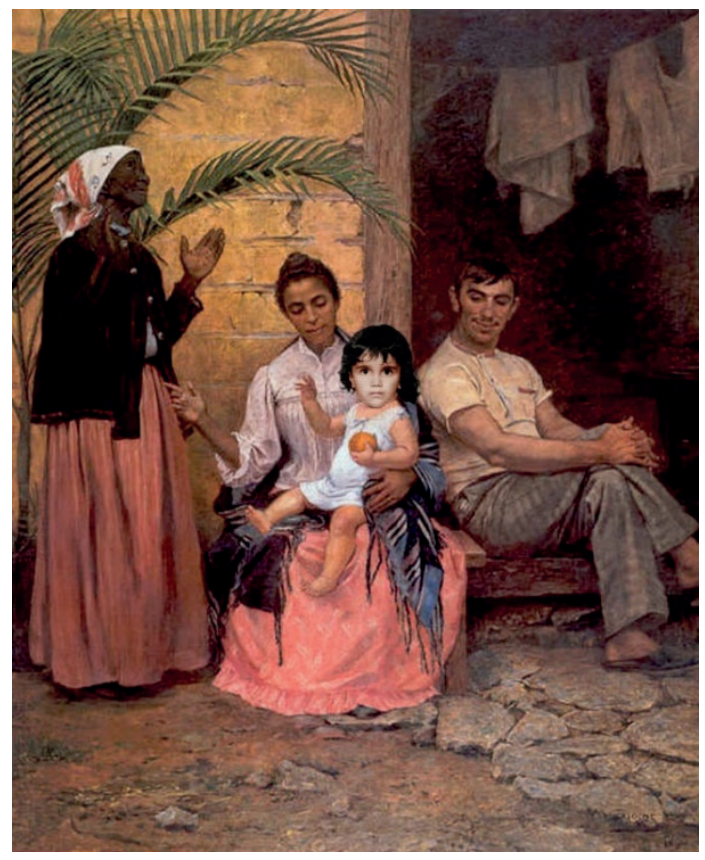

Figura 07 - Montagem de Bruno Augusto, a partir da obra Operários, de Tarsila do Amaral (1933). Fotoperformance.

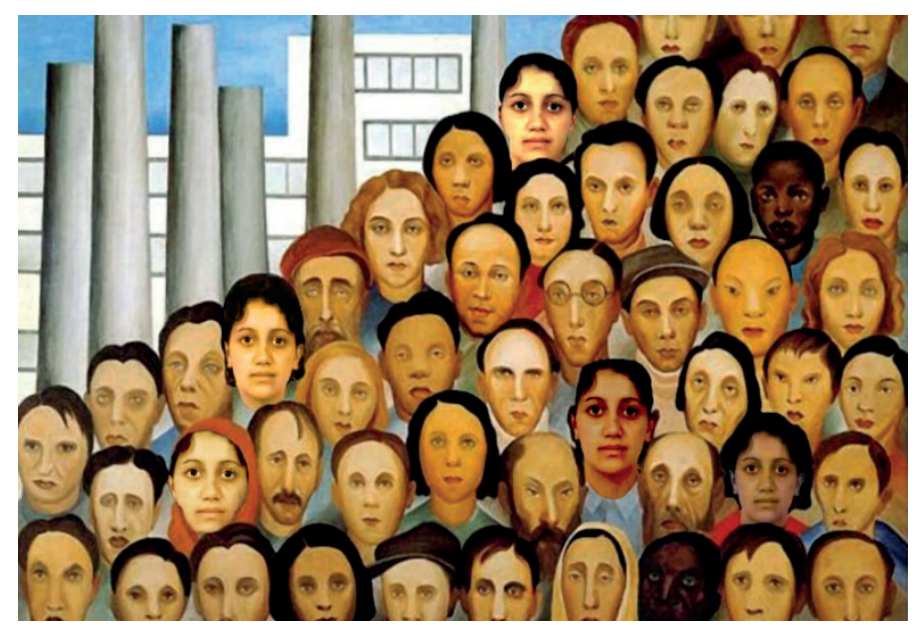

As intervençôes nas obras produziram diferentes efeitos em minha subjetividade: no caso da obra Operários, a imagem de meu rosto em meio aos trabalhadores retratados por Tarsila do Amaral me trouxe um sentimento de integraçâo e de pertencimento, e me fez reconhecer também a minha história como trabalhadora, na qual atuei em tantos e tăo diversos serviços (vendedora, garçonete, atriz, secretária, professora, etc.). Já a imagem de meu rosto na obra A Redençâo de Cam 
me trouxe tristeza e desconforto, pois me conscientizou da violência histórica que meu corpo, involuntariamente, carrega, como um corpo mestiço de pele clara no Brasil.

b) Produçâo textual

A produçấo textual iniciou-se antes mesmo da produçâo de imagens, e num primeiro momento se deu de forma integrada ao meu processo de psicoterapia. Num segundo momento, passei a tratar esse material com a intençâo de integrá-lo à performance. Surgiu a dúvida se esse texto seria dito ou nâo por mim durante a açâo, mas acabei optando por compartilhá-lo de forma escrita, e exposto junto às imagens produzidas. $O$ texto expóe, em linguagem poética, algumas questōes aqui já colocadas, conforme exemplificado no trecho abaixo:

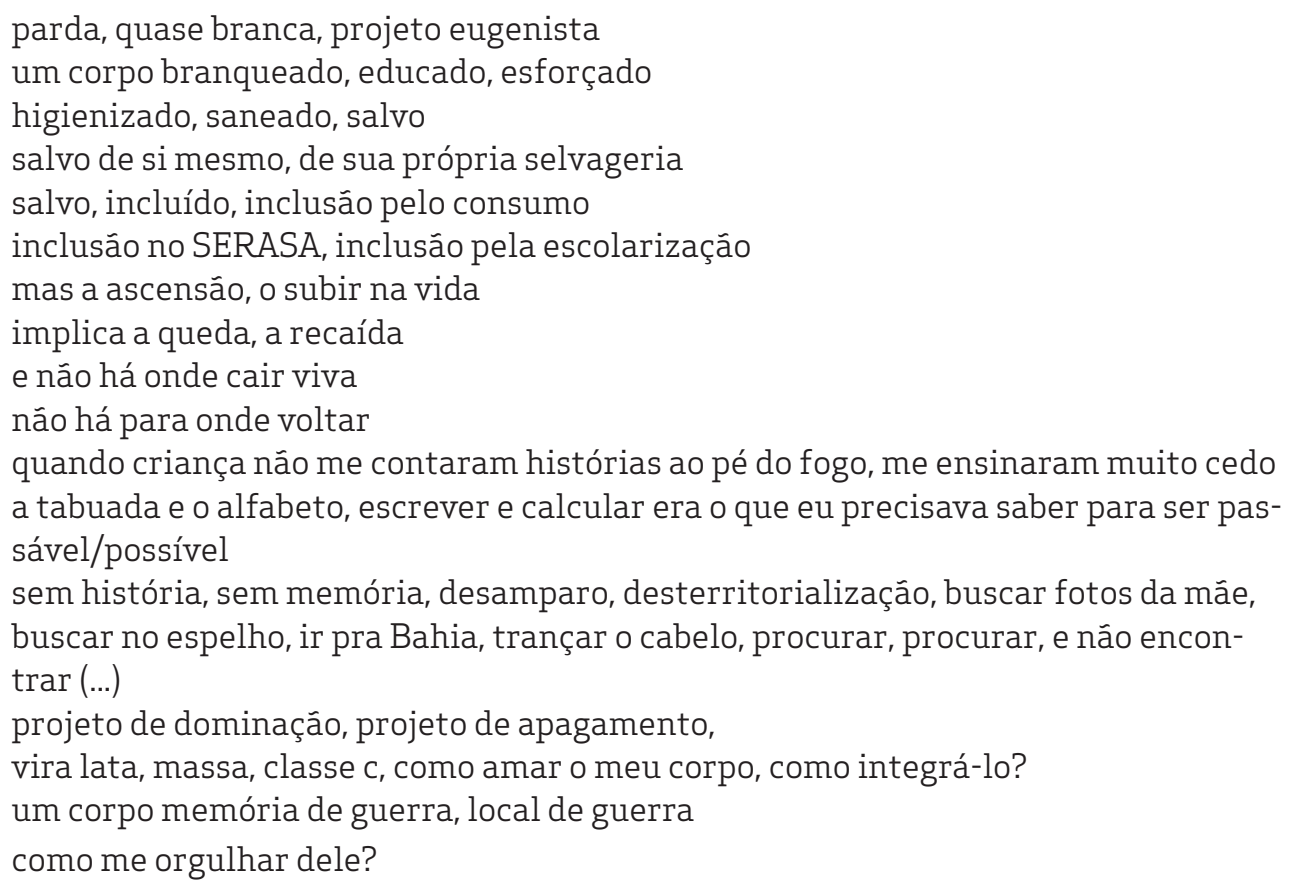

c) Açōes

A açăo performática foi realizada por duas vezes em 2018, a primeira em setembro, em um evento cultural no Teatro 171, em Belo Horizonte/MG, junto a outras duas açōes performáticas e ao funcionamento do bar do espaço. Em dezembro, a açâo foi realizada no espaço cultural Casulo, em Dourados/MS, em um evento que reuniu também apresentaçóes de cenas curtas. O roteiro da açăo foi o mesmo, tendo sido adaptado em relaçâo à configuraçăo do espaço, horário (no Teatro 171 foi feito às $22 \mathrm{~h}$, no Casulo às $18 \mathrm{~h}$ ) e outras questóes relacionadas ao ambiente, como perfil do evento e do público.

Para a realizaçâo dessa performance, primeiramente escolhi um espaço para me colocar, no qual ficasse visível para a maioria das pessoas, mas também náo as intimidasse, permitindo que me ignorassem, se quisessem. Nos três locais, esse espaço foi próximo a uma parede, e nessa parede afixei algumas das imagens produzidas anteriormente e impressas em papel fotográfico, bem como trechos do texto acima citado. Um pouco à frente, me instalei em pé de calcinha e sutiă em um 
pequeno tablado e em outro suporte (mesa ou tablado) instalei meu computador, no qual os dois vídeos acima referidos foram sendo executados em looping. Junto a mim também instalei uma placa com os dizeres: "Me pinte como você me vê" e abaixo as opçôes "preta" (associada à cor preta), "branca" (associada à cor branca), "indígena" (associada à cor vermelha) e ao lado disponibilizei tintas guache dessas cores e pincéis. Permaneci em pé sem dizer nada por cerca de uma hora, à disposição de quem quisesse pintar o meu corpo.

Transcrevo abaixo as anotaçōes de minhas percepçōes durante a realizaçăo das açōes pela primeira e pela segunda vez, em dois espaços diferentes:

- Teatro 171: Uma jovem negra ao me olhar pela primeira vez me lançou uma expressâo de raiva e indignaçăo. Algum tempo depois, ela retornou e ficou olhando de longe. Poucas pessoas negras interagiram, porém, pessoas negras eram minoria no espaço/evento. Náo havia pessoas indígenas no espaço/evento. Um homem negro pintou minha boca e nariz de branco. Me senti mal ao ter a boca pintada de branco, pensei imediatamente que meu discurso era branco, e sendo a própria performance um discurso, também a performance era branca. Foi especialmente significativo, pois todas essas reflexôes sobre identidade racial começaram a partir de uma reflexâo sobre meu lugar de enunciaçâo como artista. Meu nariz também foi pintado de branco, e isso também me desestabilizou, pois meu nariz é algo em meu rosto que identifico como náo branco. Um jovem mestiço de pele clara me olhou durante muito tempo, também olhei para ele e pude perceber que houve entre nós uma identificaçấo, em relaçâo às questōes abordadas. O homem negro que havia pintado minha boca de branco retornou e fez nova interaçăo, desenhando em meu peito uma interrogaçáo em preto. Ao final da açăo, fui me olhar no espelho e ver o resultado das interaçōes. Me surpreendi com o predomínio da cor vermelha e que as pinturas remetessem a desenhos indígenas. Acredito que isso pode ter acontecido justamente porque em Belo Horizonte a presença indígena năo é forte como em Dourados, assim parece mais fácil para o público me associar à identidade indígena sem confrontar, em seu cotidiano, a existência de indígenas reais. Também pode existir uma certa nostalgia da identidade indígena presente em muitos(as) brasileiros(as), incluso em mim mesma, no contexto da performance. Outro elemento que pode ter contribuído para o predomínio do uso da cor vermelha, é a necessidade de evitar a tensâo entre as cores preta e branca, tensâo que parece estar em cena num espaço teatral como aquele, a partir do recente reflorescimento do teatro negro na capital mineira.

- Espaço Cultural Casulo: A interaçăo năo foi tăo grande como no Teatro 171, acredito que por estar em meu meio social, junto a uma rede de amigos e conhecidos com quem convivo cotidianamente. A maior parte das pessoas evitou me olhar de perto ou diretamente e nâo interagiu, permanecendo na observaçăo à distância. Novamente a maioria das pessoas presentes no evento eram brancas, havendo poucas pessoas negras e nenhuma pessoa indígena. Percebo como a realizaçáo da performance me leva a ter esse olhar para os espaços culturais que frequento 
e nos quais me apresento, e percebê-los de forma mais consciente como espaços predominantemente brancos. Novamente uma pessoa negra pintou o meu rosto de branco, desta vez foi um estudante do curso em que leciono, o que me levou a me perceber como uma artista/professora branca. Desta vez, tal percepçăo já năo foi tăo incômoda, mas pude integrar essa dimensáo com mais facilidade em minha identidade. Várias pessoas brancas misturaram as três cores para me pintar, porém pude perceber que o resultado era decepcionante para essas pessoas, pois o tom alcançado pela mistura era próximo ao roxo escuro, o que năo correspondia ao meu tom de pele. Uma pessoa de ascendência oriental enfeitou os meus cabelos com uma flor amarela que colheu no espaço, o que me levou a refletir se foi algo aleatório ou se ela buscou representar a si e a sua etnia em meu corpo, por meio dessa cor. O resultado final da interaçâo revelou um equilíbrio entre a utilizaçâo das três cores, e o predomínio de motivos lúdicos e traços leves.

Em ambos os espaços, percebi que a performance comunicou mais com pessoas que li como mestiças, pardas, ou negras de pele clara, possivelmente por compartilharem das mesmas questōes. Pude perceber isso em contatos visuais durante a performance, mas também em comentários recebidos após, vindos de artistas negras(os) e mestiças(os) de pele clara presentes nas açôes. De forma geral, a realizaçăo das duas açôes me expôs a tensôes raciais antes năo experimentadas. Em especial no Teatro 171, receava que pessoas negras coletivamente rechaçassem a performance, o que năo receava que viesse de pessoas brancas. Assim, apesar de estar tematizando minha condiçăo de năo branca, tragicamente me sentia mais segura entre pessoas brancas. Também me preocupou nos momentos em que percebi pintarem meu rosto com a cor preta, por rejeitar a ideia de me associar ao blackface ${ }^{13}$. Ao mesmo tempo, foi desconfortável ser pintada de branco e é curioso perceber essa dificuldade de integrar em minha subjetividade a identidade branca. Robin DiAngelo (2011), em seu artigo White Fragility (Fragilidade Branca), nos alerta para as dificuldades das pessoas brancas de lidarem com as tensôes raciais, devido a viverem segregadas e protegidas em ambientes brancos e envoltas em situaçóes de conforto racial. De acordo com DiAngelo, ao se confrontarem com a exposiçâo do racismo e do privilégio branco, pessoas brancas respondem em geral de forma defensiva, apresentando incapacidade emocional de lidar com a tensáo racial, com o reconhecimento de sua branquitude e de sua inserçâo em um grupo social privilegiado. Para a pesquisadora, a recusa das pessoas brancas de se colocarem no lugar da branquitude contribui para a manutençăo do racismo. A partir do meu desconforto em relaçáo à cor branca em meu rosto, pude perceber esse sentimento de fragilidade branca durante as açōes, mas também em relaçấo às questôes que originaram a performance: o questionamento de minha identidade racial como pessoa e como artista.

13 Convencionou-se a chamar como blackface a prática de atores (atrizes) brancos (as) pintarem o rosto (e eventualmente também pescoço, braços e pernas) de preto ao interpretarem personagens negros(as). Tal prática tem sido combatida no Brasil desde o surgimento do TEN (Teatro Experimental do Negro) na década de 1940, pois além de ser uma consequência da exclusāo de artistas negras(os) do teatro profissional, também contribui para uma representaçâo caricata e estereotipada. 
Por meio de todo esse processo criativo denominado Parda, venho percebendo que pouco se fala da experiência racial de pessoas mestiças de pele clara em nosso país, e, quando se fala, se fala a partir da constataçăo de privilégios das pessoas mestiças em relaçáo a pessoas negras ou indígenas. Longe de negar esses privilégios sociais e econômicos em nossa sociedade racista, nossa intençăo é expor, no âmbito subjetivo, aspectos negativos embutidos no "pacote do branqueamento", adquirido muitas vezes de forma inconsciente e compulsória por pessoas mestiças de pele clara. Em meu caso, a performance tem me trazido a consciência do branqueamento e a angústia dessa percepçáo difusa e lacunar de minha própria origem, que se manifesta na sensaçấo de identidade roubada/sequestrada.

Para Souza (1983), pessoas negras podem se conscientizar da imagem negativa construída pelo mito negro e abandonar o ideal branco ao qual săo impelidas no processo de ascensăo social, tornando-se verdadeiramente negras:

Ser negro é, além disso, tomar consciência do processo ideológico que, através de um discurso mítico acerca de si, engendra uma estrutura de desconhecimento que o aprisiona numa imagem alienada, na qual se reconhece. Ser negro é tomar posse desta consciência e criar uma nova consciência que reassegure o respeito às diferenças e que reafirme uma dignidade alheia a qualquer nível de exploraçấo. Assim, ser negro năo é uma condiçấo dada, a priori. É um vir a ser. Ser negro é tornar-se negro. (SOUZA, 1983, 77)

O desenvolvimento da performance Parda e as reflexôes que aqui realizo săo parte do desejo de afirmar minha dignidade, na inspiraçâo de Souza. Nâo se trata, porém, de afirmar uma identidade negra ou indígena, e nesse sentido compreendo a argumentaçăo de Akotirene, de que a reivindicaçăo de pessoas de pele clara por uma identidade negra năo procede:

A identidade branca desmascara quem se passa por negro sem sê-lo, dando as chances políticas de ser branco de verdade. (...) A interseccionalidade dispensa individualmente quaisquer reivindicaçôes identitárias ausentes da coletivamente constituída, por melhores que sejam as intençóes de quem deseja se filiar à marca fenotípica da negritude (AKOTIRENE, 2019, p.47)

Mesmo tendo vínculos afetivos e históricos com a negritude, năo posso reivindicar uma identidade negra, seja por reconhecer a estrutura pigmentocrática do racismo brasileiro que náo atua de forma decisiva sobre minha pele clara, seja simplesmente por năo ter passabilidade como pessoa negra. Por outro lado, năo conseguiria, sem grande sofrimento subjetivo, abraçar uma identidade branca, como nos propóe a pesquisadora Joyce Souza Lopes: sendo também ela mestiça de pele clara, buscou construir para si uma identidade branca antirracista, pois estando inserida no movimento negro e tendo a pele clara, náo se sentia à vontade para portar uma identidade negra, mesmo sendo de origem mestiça, ou, como prefere dizer, mesmo estando em "entremeios raciais" (2017, ebook). Lopes reconhece que no Brasil os conceitos de racialidade estăo construídos socialmente a partir da cor da pele e năo da origem, porém apesar de seu esforço por assumir uma posiçăo racial (branca), ainda assim permanece a complexidade de sua posiçấo. Nas palavras de Lopes: 
talvez isso fosse mais simples, ou até menos desconfortável, se a minha identidade racial năo fosse questionada o tempo todo, se a configuraçăo do "meu lugar" nâo fosse tâo ambíguo, híbrido e inseguro. Quando afirmo uma identidade racial branca, construída a partir de uma relaçāo dialética entre sujeitos do Movimento Negro, ponho em xeque uma série de dúvidas e inconstâncias, levando em consideraçăo que apresento um resultado estereótipo, talvez nâo tăo feliz, do processo de embranquecimento racial via miscigenaçấo - sendo filha de uma relaçăo inter-racial entre uma mulher negra e um homem branco (um homem branco também entre aspas). Assim, sou daquela/es da linha racial năo nítida que, ouso dizer, assume sua raça/cor a partir do que lhe é conveniente e estratégico, mas também conforme o processo de letramento racial em que, via de regra, as classificaçôes sociorraciais existem antes mesmo da autoidentificaçăo do sujeito. (LOPES, 2017, ebook)

A relativa "escolha" que a pessoa parda pode fazer de sua identidade, e que a constitui ora como "privilegiada" (quando se branqueia) ora como "impostora" (quando se enegrece), é também, ao revés, uma negação de ambas as possibilidades.

No contexto de seu engajamento na luta antirracista, Lopes năo propóe uma categoria identitária mestiça, e recusa o termo pardo, por associá-lo ao colonialismo, utilizando a expressăo "entremeios raciais" para tratar da especificidade de seu lugar de fala. Apesar disso, a pesquisadora reconhece que o conceito de branquitude é insuficiente para tratar de sua experiência, e problematiza

\begin{abstract}
os aspectos subjetivos, econômicos, sociais e culturais que fazem desses sujeitos diferenciados de outros seres racializados; o que torna possível as múltiplas existências e racializaçóes de uma corporeidade aparentemente semelhante; onde e como se reproduz o hibridismo, o paradoxo, a ambivalência e o fetiche racial no cotidiano dos referidos. (...) Deixo explícito que há uma ausência e emergência de perspectivas, no Brasil, que consigam superar a centralidade do debate sobre o entremeios raciais a partir da obra de Gilberto Freyre e seus dissidentes, mesmo que em contrariedade; que consigam tratar dessa questăo sem reducionismos binaristas que têm a/o mestiça/o como produto do paraíso ou do inferno racial; que, por fim, levem-nos a deixar de nos definirmos pelas categorias colonizadoras (LOPES,2017, ebook)
\end{abstract}

Em consonância com Lopes, também me ressinto de um discurso sobre minha constituiçăo mestiça pautado sobretudo em Gilberto Freyre, seja na afirmaçăo, seja na negaçăo de seu ideal de mestiçagem, um discurso que me prende à lógica colonial. Rejeito também a pacificaçăo de meu problema racial por meio da adoçâo da categoria de branquitude como construçăo identitária, pois tal categoria, como reconhecido pela própria Lopes, é insuficiente para tratar de minha experiência. Resta-me expor meu corpo como esse problema sem soluçăo, que resiste a toda e qualquer estrutura teórica e política, e que permanece continuamente esse objeto sem nome que deseja reconhecimento. Durante a realizaçăo da performance, ao disponibilizar meu corpo para a livre significaçăo e interferência dos(as) outros(as), exponho que construir um relato racial de si náo é uma tarefa realizada individualmente e de forma livre, mas uma construçâo social que se dá em diálogo com o regime de verdade do dualismo racial, e convido os(as) outros(as) para que, por intermédio de seus olhares sobre meu corpo, possamos desestabilizar esse regime. De acordo com Butler: 
o que posso "ser", de maneira bem literal, é limitado de antemăo por um regime de verdade que decide quais formas de ser serăo reconhecíveis e năo reconhecíveis. [...] Isso náo significa que dado regime de verdade estabeleça um quadro invariável para o reconhecimento; significa apenas que é em relaçăo a esse quadro que o reconhecimento acontece, ou que as normas que governam o reconhecimento săo contestadas e transformadas. [...] Pôr em questăo um regime de verdade, quando é o regime que governa a subjetivaçăo, é pôr em questăo a verdade de mim mesma e, com efeito, minha capacidade de dizer a verdade sobre mim mesma, de fazer um relato de mim mesma. (BUTLER, 2015a, p. 35)

Invisto na potência justamente do que me constitui racialmente, que é o desconhecimento de minha origem e a incapacidade de uma definiçâo racial nítida e peremptória, partindo das recusas: a) a assumir uma identidade branca, o que seria aceitar com docilidade a violência do branqueamento; b) a reivindicar uma identidade negra ou indígena, o que seria contribuir para a estrutura racista de invisibilizar a experiência de pessoas negras e indígenas; c) a assumir uma identidade mestiça, na concepçăo pacificadora de uma identidade nacional fundada na sensualidade da narrativa freyriana. A partir dessas recusas é que se estrutura a performance Parda, e năo a partir da reivindicaçăo de uma identidade racial mestiça como uma estrutura fixa e estável. O que move a atriz/dramaturga/performer é o desejo de reconhecimento:

Se e quando, na tentativa de conceder ou receber um reconhecimento que é frustrado repetidas vezes, eu ponho em questăo o horizonte normativo em que o reconhecimento acontece, esse questionamento faz parte do desejo de reconhecimento, desejo que pode năo ser satisfeito e cuja insatisfabilidade estabelece um ponto crítico de partida para o questionamento das normas disponíveis. (BUTLER, 2015a, p. 37)

Ao pedir para que me pintem, o que peço é que me vejam e que me reconheçam. O relato de mim mesma que apresento é meu próprio corpo, que desconheço, e que por isso pede por reconhecimento: “De certa forma, ser um corpo é o mesmo que ser privado de uma recordaçâo completa da própria vida. Meu corpo tem uma história da qual náo posso ter recordaçôes". (BUTLER, 2015a, p. 54) Para Butler, a responsabilidade ética năo decorre de um(a) sujeito(a) que se conhece por completo e que tem uma identidade coerentemente constituída, mas sim a partir do próprio reconhecimento da impossibilidade de um relato completo de si, e até da despossessâo de si mesma(o) na relaçâo com os(as) outros(as):

o relato que faço de mim mesma é parcial, assombrado por algo para o qual năo posso conceber uma história definitiva. Năo posso explicar exatamente por que surgi dessa maneira, e meus esforços de reconstruçáo narrativa sâo sempre submetidos à revisăo. Há algo em mim e de mim do qual náo posso dar um relato. Mas isso quer dizer que, no sentido moral, eu náo sou responsabilizada por aquilo que sou e faço? Se descubro que, apesar de meus melhores esforços, ainda resta certa opacidade e que náo posso relatar a mim mesma totalmente para o outro, seria isso um fracasso ético? Ou é um fracasso que suscita outra disposiçăo ética no lugar de uma noçăo plena e satisfatória da responsabilizaçăo narrativa? Nessa afirmaçăo de transparência parcial, existe a possibilidade de reconhecer uma relacionalidade que me vincule à linguagem e ao tu de maneira mais profunda do que antes? A relacionalidade que condiciona e cega esse "si-mesmo" náo é, de maneira precisa, um recurso indispensável para a ética? (BUTLER, 2015a, p. 56) 
Segundo Butler (2015a), ao reconhecer a minha própria opacidade em relaçăo a mim mesma, estabeleço uma relaçáo ética com o(a) outro(a) na qual năo exijo dele(a) que seja idêntico(a) a todo momento, mas permito que nosso desejo mútuo por reconhecimento seja renovado continuamente, desafiando inclusive os regimes de verdade que estabelecem as normas de reconhecimento. Tal disposiçăo encontra-se presente na dramaturgia da performance, na qual exponho ao público a minha própria impossibilidade de autodefiniçăo, ou as várias lacunas e opacidades da definição parda:

\begin{abstract}
Se a identidade que dizemos ser náo nos captura e marca imediatamente um excesso e uma opacidade que estăo fora das categorias da identidade, qualquer esforço de "fazer um relato de si mesmo" terá de fracassar para que chegue perto de ser verdade. Quando pedimos para conhecer o outro, ou pedimos para que o outro diga, final ou definitivamente, quem é, é importante nâo esperar nunca uma resposta satisfatória. Quando năo buscamos a satisfaçăo e deixamos que a pergunta permaneça aberta e perdure, deixamos o outro viver, pois a vida pode ser entendida exatamente como aquilo que excede qualquer relato que dela possamos dar. Se deixar o outro viver faz parte da definiçăo ética do reconhecimento, tal definiçăo será baseada mais na apreensáo dos limites epistêmicos do que no conhecimento. (BUTLER, 2015a, p. 61)
\end{abstract}

A realizaçâo da performance me levou a um processo de racializaçâo, processo esse marcado, entretanto, pelo fracasso e pela incompletude. Se o corpo pardo pode significar a vitória de um projeto brasileiro de branqueamento e desracializaçăo, a exposiçaáo desse corpo e o convite à sua ressignificaçáo pode acenar para a insurgência desse corpo ao regime de normas de reconhecimento ao qual está sujeito, numa tentativa de desconstruir a máscara branca fanoniana sem incorrer em apropriaçăo indevida de lugares de fala. Faz-se necessário opor-se à tendência crescente ao pensamento binário, influência talvez da cultura norte americana, no que toca às discussôes raciais em nosso país, em busca de termos decoloniais para pensar a mestiçagem. Para ressaltar o corpo insurgente que evoco, encerro o artigo com as imagens produzidas na relaçăo com os(as) outros(as) em performance. 
Figura 08 - Registro das intervençôes ao fim da performance Parda.Teatro 171, 27/09/2018.

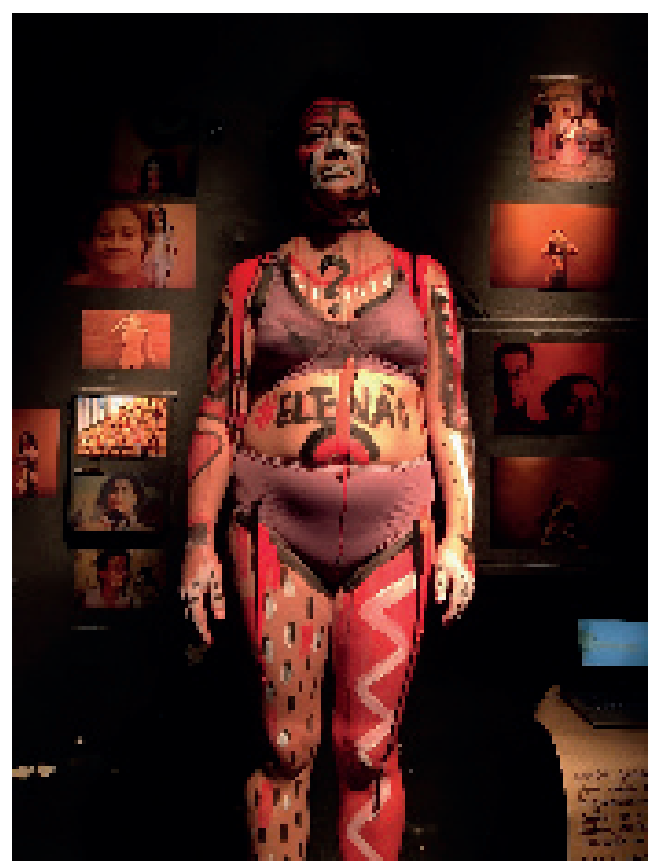

Fotógrafa: Marina Arthuzzi.

Figura 09 - Registro das intervençôes ao fim da performance Parda. Espaço Cultural Casulo, 13/12/2018.

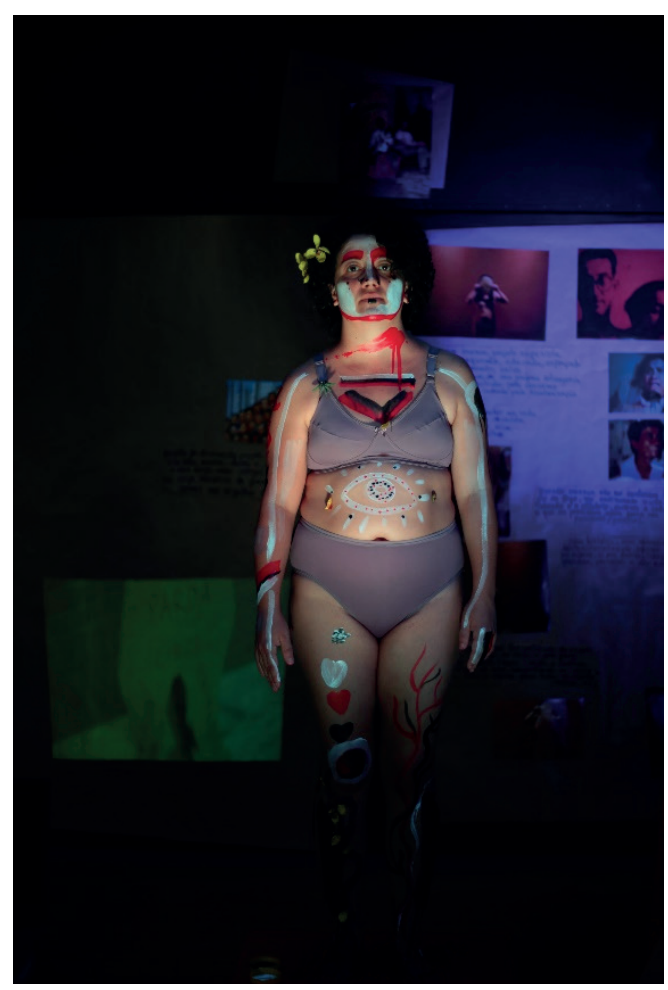

Fotógrafo: Raique Moura. 


\section{REFERÊNCIAS}

AKOTIRENE, C. Interseccionalidade. São Paulo: Polén, 2019.

ALTHUSSER, L. Ideologia e Aparelhos Ideológicos do Estado. Săo Paulo: Martins Fontes, 1970.

COMECE A PENSAR. [2019]. Corrida Feita de Privilégio e Desigualdade. Disponível em: 〈https://www.youtube.com/watch?v=L177yGji8eM>. Acesso em: 6 dez. 2019.

BUTLER, J. Relatar a si mesmo: crítica da violência ética. Belo Horizonte: Autêntica Editora, 2015a.

Problemas de Gênero: Feminismo e subversăo da identidade. Rio de Janeiro: Civilizaçăo Brasileira, 2015b.

CHAMORRO, G. História Kaiowa. Das origens aos desafios contemporâneos. São Bernardo do Campo: Nhanduti Editora, 2015.

DIANGELO, R. White Fragility. International Journal Of Critical Pedagogy, v. 3, n. 3, p. 54-70, 2011. Disponível em: <https://libjournal.uncg.edu/ijcp/article/viewFile/249/116>. Acesso em: 24 out. 2018.

FANON, F. Pele negra, máscaras brancas. Salvador: EDUFBA, 2008.

FREYRE, G. Casa-grande \& senzala: formaçáo da família brasileira sob o regime da economia patriarcal. Săo Paulo: Global, 2003.

Sobrados e mucambos. Rio de Janeiro: José Olympio, 1951.

IBGE. Censo Demográfico 2010 - Características da populaçăo e dos domicílios Resultado do universo. Rio de Janeiro: IBGE, 2011. Disponível em: <https://biblioteca.ibge.gov.br/visualizacao/periodicos/93/cd_2010_caracteristicas_populacao_ domicilios.pdf >. Acesso em: 13 set. 2018.

ID_BR. [2019] Jogo do privilégio branco. Disponível em: <https://www.youtube.com/ watch?v=MuOE3IJZoZU . Acesso em: 6 dez. 2019.

LOPES, J. S. Quase negra tanto quanto quase branca: autoetnografia de uma posicionalidade racial nos entremeios. In: CARDOSO, L.; MÜLLER, T. M. P. (Org.) Branquitude: estudos sobre a identidade branca no Brasil. Curitiba: Appris, 2017, ebook.

MUNANGA, K. Rediscutindo a mestiçagem no Brasil: identidade nacional versus identidade negra. $5^{a}$ ediçáo, revista e ampliada. Belo Horizonte: Autêntica Editora, 2019.

PIRES, B. 'Meu neto é um cara bonito, viu ali? Branqueamento da raça', diz Mourăo. O Estado de S. Paulo, Sáo Paulo, 06 out. 2018, online. Disponível em: <https://politica.estadao.com.br/noticias/eleicoes, meu-neto-e-um-cara-bonito-viu-ali-branqueamento-da-raca-diz-mourao,70002535826>. Acesso em: 7. out. 2018. 
PONTES, J. C.; SILVA, C. G. Cisnormatividade e passabilidade: deslocamentos e diferenças nas narrativas de pessoas trans. Periódicus, Salvador, v.1, n. 8, p. 396-417, nov. 2017-abr. 2018. Disponível em: <http://www.portalseer.ufba.br/index.php/ revistaperiodicus>. Acesso em: 26 fev. 2019.

RACIONAIS MC'S. (2002). A vida é desafio. Disponível em: <https://www.youtube. com/watch?v=PQin7NsK7SM>. Acesso em: 6 dez. 2019

RIBEIRO, D. O que é lugar de fala? Belo Horizonte: Letramento, 2017.

SOUZA, N. S. Tornar-se negro: as vicissitudes da identidade do negro brasileiro em ascensăo social. Rio de Janeiro: Ediçōes Graal, 1983.

STEPAN, N. L. Eugenia no Brasil, 1917-1940. In: Hochman, G.; Armus, D. (Org.). Curar, controlar, cuidar: ensaios históricos sobre saúde e doença na América Latina e Caribe. Rio de Janeiro: Editora Fiocruz. p.331-391. 2004. Disponível em: <https:// pdfs.semanticscholar.org/7b3c/ac6eb679167b4414dla608aa741a23093bbe. pdf> Acesso em: 16 mar. 2020. 